\title{
Cytochrome P450 Biodiversity and Plant Protection
}

\author{
Hideo OHKawa, Hisae TsujII, Miyuki Shimoji, Yoshiro ImajuKu \\ and Hiromasa IMAISHI* \\ Department of Biological and Environmental Science, Faculty of Agriculture, Kobe University, \\ and * Center for Cooperative Research and Development, Kobe University, Rokkodaicho 1-1, \\ Nada-ku, Kobe 657-8501, Japan
}

(Accepted February 20, 1999)

\begin{abstract}
Cytochrome P450 monooxygenases play an important role in detoxification and/or activation of xenobiotics including agrochemicals as well as in the modes of action of agrochemicals including fungicides, plant growth regulators, insecticide synergists and herbicide safeners. Current genome sequencing revealed that $\mathbf{P} 450$ genes are distributed into the five kingdoms of life: bacteria, protoctista, plants, animals and fungi, and a large number of P450 genes occur in animal and plant species. Particularly, Arabidopsis is estimated to have around 400 genes. Biochemical characterization of these P450 enzymes is important for understanding their physiological functions. In higher plants, Arabidopsis T-DNA mutant lines appear to be useful for analysis of their physiological functions. In addition, the yeast expression system is practically important for analysis of their enzymatic functions. Engineering of transgenic plants expressing certain P450 species is also important for crop breeding with useful traits including selective herbicide tolerance and phytoremediation.
\end{abstract}

Key words: cytochrome P450, insecticide resistance, herbicide resistance, Arabidopsis T-DNA mutants, transgenic plants, phytoremediation.

\section{Introduction}

Cytochrome P450 monooxygenases catalyze oxidative reactions of a wide variety of endogenous or exogenous lipophilic compounds. The enzyme systems consist of 3 domains: FAD, Fe-S or FMN and heme. The FAD and $\mathrm{Fe}-\mathrm{S}$ or FMN domains form an electron transfer chain from NADPH or NADH to the heme domain which catalyze oxidative reaction. These domains are composed of 1,2 or 3 proteins among prokaryotes and eukaryotes. In prokaryote cells, cytochrome $\mathbf{P} 450$ enzyme system mainly consists of 3 components: cytochrome P450 (P450), ferredoxin and NAD(P)Hferredoxin reductase locate in the cytosol. In eukaryote cells, the P450 enzyme system located in the mitochondria consists of 3 components: cytochrome P450 (P450), ferredoxin and NADPH-ferredoxin reductase (ferredoxin reductase), and the P450 system in the microsomes is 2 components; P450 and NADPH P450 oxidoreductase (P450 reductase). These are membrane-bound enzymes except ferredoxin.

It is well known that P450 monooxygeneses involved in the detoxification and/or activation of xenobiotics including pesticides. In addition, certain P450 species are targets of the action of agrochemicals including fungicides, plant growth regulators, insecticide synergists and herbicide safeners.

\section{P450 Biodiversity}

Genome sequencing of dozens of bacteria and selected model organisms provids an unprecedented look into P450 biodiversity (Table 1) ${ }^{1,2)}$ The complete set of P450 genes from many species is now available and all the five kingdoms of life: bacteria, protoctista, plants, animals and fungi have $\mathrm{P} 450$ genes. Estimates for this divergence are between 3.85 and 3.5 billion years ago, before photosynthesis evolved. A date before photosynthesis also means that $\mathrm{P} 450$ species preceded molecular oxygen in the environment, so these early $\mathrm{P} 450$ species must have been doing chemical reactions without molecular oxygen. Proteobacteria and cyanobacteria were the sources of mitochondria and chloroplasts, so they could have been P450 donors to eukaryotic cells. Fungi have relatively few $\mathrm{P} 450$ species. Yeast has only three in the complete genome (CYP51, CYP56 and CYP61) (Table 2). Only CYP51 is haploid lethal and it has been found in other organisms. Therefore, P450 species are not generally useful to fungi, except in the synthesis of sterols. 
Table 1 P450 biodiversity.

$\begin{array}{cr}\begin{array}{c}\text { Distribution : bacteria, protoctista, plants, } \\ \text { animals, fungi }\end{array} \\ \text { Saccharomyces cerevisiae } & 3 \text { genes } \\ \text { Caenorhabditis elegans } & 80 \text { genes } \\ \text { Drosophila melanogaster } & 80 \text { genes } \\ \text { Mammals } & 50-70 \text { genes } \\ \text { Arabidopsis thaliana } & 400 \text { genes } \\ \text { Function : xenobiotic metabolism } & \\ \text { secondary metabolism } & \end{array}$

Table 2 P450 species in Saccharomyces cerevisiae.

$\begin{array}{ll}\text { CYP51 } & \text { sterol 14-demethylase } \\ \text { CYP56 } & N \text {-formyl tyrosine oxidase } \\ \text { CYP61 } & \text { sterol 22-desaturase }\end{array}$

Other more specific uses in fungi involve protection against plant toxins, fungal toxin biosynthesis and alkane utilization. Plants and animals have many P450 species that seem to be a hallmark of multicellular organisms. The genome sequencing of Caenorhabditis elegans will be finished soon. So far, C. elegans has 80 P450 genes, with more than half occurring in a unique $C$. elegans cluster on phylogenetic trees. These were probably all derived from a single ancestor that was greatly amplified in the $C$. elegans lineage. Insects seem to have done this also. Drosophila melanogaster was estimated to have about $80 \mathrm{P} 450$ genes. As organisms become more complex, they seem to arbitrarily select a P450 to amplify to meet their needs. Up to now, the model plant Arabidopsis thaliana was found to have about 170 P450 genes in 41 families. Since the genomic sequencing in Arabidopsis will complete not very far so there will probably be around $400 \mathrm{P} 450$ genes in Arabidopsis. This is a much larger number than is found in mammals ( 50 to 70 genes), and it probably represents the plant strategy of making large numbers of secondary metabolites, many of which require $\mathrm{P} 450$ hydroxylation reactions.

P450 enzymes are encoded by a highly divergent gene superfamily. By definition, P450 sequences related at the family level are $>40 \%$ identical to one another at the level of amino acids, those related at the subfamily level are $>55 \%$ identical and those related at the allelic variant level are $>97 \%$ identical. In the standardized $\mathrm{P} 450$ nomenclature, P450 sequences are named with a "CYP" followed by a number (i.e., 1, 2, 3) designating the gene family, a capital letter (i.e., A, B, C) designating the gene subfamily and a number designating a particular gene.

\section{Insect $\mathbf{P 4 5 0}$ species}

In less than 10 years, we have gone from a single insect sequence of CYP6A1 to over 150 sequences in 7 families
Table $3 \quad \mathrm{P} 450$ species in insects.

\begin{tabular}{ll}
\hline CYP Number & \multicolumn{1}{c}{ Function } \\
\hline CYP4C7 & juvenile hormone biosynthesis \\
CYP4D10 & alkaloid resistance \\
CYP6A1 & DDT resistance \\
CYP6A2 & DDT resistance and organophosphorus \\
& insecticide metabolism \\
CYP6B4 & furanocoumarin detoxification \\
CYP6D1 & pyrethroid resistance \\
CYP9A1 & thiodicarb resistance \\
CYP12A1 & organophosphorus insecticide resistance \\
CYP12B1 & 1 $\alpha, 25$ dihydroxy-D3 24-hydroxylase \\
CYP18 & induction wrth 20-hydroxyecdysone \\
\hline
\end{tabular}

(Families 4, 6, 9, 12, 15, 18 and 28) (Table 3). ${ }^{3-12)} \mathrm{A}$ major focus of recent research on insect $\mathrm{P} 450$ species has been their role in the detoxification of xenobiotics. In this regard, members of the CYP6 family have attracted interest, initially due to their close relationship to the vertebrate CYP3 P450 species which play a key role in xenobiotic and toxin metabolism. Subsequently, a number of insect CYP6 P450 species have been implicated in plant allelochemical and insecticide metabolism. However, the greater diversity of family 4 sequences in insects compared to their vertebrate homology and additional studies on induction by xenobiotics suggest that family 4 as well as other P450 families (e.g., family 28) may also play a significant role in insect detoxification mechanisms. Also, these $\mathbf{P} 450$ species appear to be related to insecticide resistance as well as the targets of insecticide synergists.

Insects in the Papilio (swallowtail) family have evolved P450 enzymes capable of detoxifying the allelochemical furanocoumarin. CYP6B1 and CYP6B3 in Papilio polyxenes (black swallowtail), and CYP6B4 in $P$. glaucus (tiger swallowtail) mediate furanocoumarin detoxification. These P450 species seem to be involved in plant-insect interactions.

Multiple mitochondrial P450 species may have been recruited in insects to metabolize xenobiotics in addition to their possibly ancestral functions in steroidogenesis. The most abundant of three mitochondrial-like cDNA clones from house flies, CYP12A1 was expressed in Escherichia coli and purified. Subcellular localization of CYP12A1 in the fly by immunogold histochemistry established the mitochondrial nature of this protein. In a reconstituted system with bovine adrenodoxin, adrenodoxin reductase and NADPH, the purified CYP12A1 metabolized a variety of insecticides and other xenobiotics, but did not metabolize ecdysteroids, juvenoids or fatty acids. CYP12A1 mRNA levels are constitutively higher in an insecticide-resistant strain than in a susceptible strain, and this trait maps to chromosome II in the house fly, where the constitutive overex- 
pression of the pesticide-metabolizing microsomal CYP6A1 also maps.

Phenobarbital-like induction of the Drosophila CYP6A2 gene was studied using transgenic CYP6A2GFP (Green Fluorescent Protein) flies. The pattern of induction, and particularly the stunning diversity of chemistries leading to CYP2B induction in mammals, are conserved in Drosophila, indicating that P450 species from widely divergent families can be recruited to ancient and conserved regulatory pathways.

A novel P450 species from the endocrine glands that produce the sesquiterpenoid insect juvenile hormone (JH) has been recruited from one of the most diverse insect P450 families: CYP4C7 was isolated from a cDNA library of the corpora allata (CA) of females of the cockroach, Diploptera punctata. CYP4C7 is expressed selectively in the CA, and its expression could not be detected in the fat body, corpora cardiaca or brain. Levels of CYP4C7 mRNA were closely linked to the activity cycle of the CA, as the CYP4C7 message is predominantly expressed when the gonadotropic activity of the CA is shut off in adult females. The CYP4C7 protein was produced in $E$. coli. In a reconstituted system with insect $\mathbf{P} 450$ reductase, cyt $b_{5}$ and NADPH, the purified CYP4C7 metabolized 2E, 6E-farnesol to a more polar product which was identified as (10E)-12hydroxyfarnesol. CYP4C7 also metabolized other sesquiterpenoids including JH III and methyl farnesoate to their 12-trans-hydroxy metabolites. This $\omega$ hydroxylation of sesquiterpenoids appears to be a new metabolic pathway in the CA of insects and may play a role in the suppression of $\mathrm{JH}$ biosynthesis at the end of the ovarian cycle.

\section{Plant P450 species}

Over 360 P450 sequences from plants are currently known, but the function for few has been identified (Table 4). ${ }^{13-29)}$ Important P450 enzymes whose characterization remains elusive or poorly understood are; (I) the $\mathrm{C}_{14}$-demethylase (CYP51) and $\mathrm{C}_{22}$-desaturase which are important in sterol synthesis and assumed to be the targets of herbicides; (II) two enzymes that control the biosynthesis of glucosinolates in; (III) at least sixteen P450 species in the phenylpropanoid/flavonoid pathway; (IV) the benzoic acid 2-hydroxylase involved in the synthesis of salicylic acid, and allene oxide synthase (CYP74); (V) a variety of P450 species involved in the metabolism of gibberellic acids (the targets of plant growth regulators), abscisic acid, and brassinosteroids in addition to two CYP90 species already identified, and (VI) P450 enzymes responsible for herbicide metabolism (the targets of herbicide safeners) (Table 5). Many important reactions are presumed to involve $\mathrm{P} 450$ enzymes, but confirmation is lacking. The role of plant chemicals in defense against plant pathogens (bacteria,
Table 4 P450 species in plants.

\begin{tabular}{ll}
\hline CYP Number & \multicolumn{1}{c}{ Function } \\
\hline CYP51 & obtusifoliol 14 $\alpha$-demethylase \\
CYP71A5 & (3S)-citronellol 10-hydroxylase \\
CYP71A11 & chlortoluron metabolism \\
CYP71B7 & 7-ethoxycoumarin $O$-deethylase \\
CYP71C & DIBOA biosynthesis \\
CYP71C3v2 & triasulfuron 5-hydroxylase \\
CYP71E1 & p-hydroxymandelonitrile synthesis \\
CYP73 & cinnamate 4-hydroxylase \\
CYP74A & alleneoxide synthase \\
CYP74B & fatty acid hydroperoxidelyase \\
CYP75 & flavonoid 3'5'-hydroxylase \\
CYP76 & 7-ethoxycoumarin $O$-deethylase \\
CYP78A1 & fatty acid hydroxylase \\
CYP79 & tyrosine $N$-hydroxylase \\
CYP80A1 & berbamunine synthase \\
CYP80B1v7 & ( $S$ )- $N$-methylcoclaurine 3'-hydroxylase \\
CYP80B1v2 & fatty acid hydroxylase \\
CYP81B1 & fatty acid hydroxylase \\
CYP81E1 & flavonoid biosynthesis \\
CYP84 & ferulate 5-hydroxylase \\
CYP86A1 & fatty acid w-hydroxylase \\
CYP88A1 & gibberellin biosynthesis \\
CYP90A1 & cathasterone 23-hydroxylase \\
CYP90B & brassinosteroid biosynthesis \\
CYP90C1 & steroid hydroxylase \\
CYP93A1 & dihydroxypterocarpan 6a-hydroxylase \\
CYP93B1 & (2S)-flavanone 2-hydroxylase \\
CYP94A1 & cutin monomers synthease \\
CYP701A3 & ent-kaurene oxidase \\
CYP703A1 & fatty acid hydroxylase \\
\hline
\end{tabular}

Table 5 Target sites for agrochemicals.

\begin{tabular}{|c|c|}
\hline Target site & Agrochemical \\
\hline $\begin{array}{l}\text { Fungal and plant sterol } \\
\text { biosynthesis }\end{array}$ & $\begin{array}{l}\text { Antifungal and herbicidal } \\
\text { compounds }\end{array}$ \\
\hline $\begin{array}{l}\text { Fungal and plant squalene } \\
\text { epoxidase }\end{array}$ & $\begin{array}{l}\text { Antifungal and herbicidal } \\
\text { compounds }\end{array}$ \\
\hline $\begin{array}{l}\text { Plant kaurene oxidase and } \\
\text { kaurenoic acid hydroxylase }\end{array}$ & Plant growth retardants \\
\hline $\begin{array}{l}\text { Plant P450 metabolizing her- } \\
\text { bicides }\end{array}$ & Herbicide safeners \\
\hline $\begin{array}{l}\text { Insect P450 metabolizing } \\
\text { insecticides }\end{array}$ & Insecticide synergists \\
\hline
\end{tabular}

fungi) and herbivores (insects) is known in general terms but the specific $\mathrm{P} 450$ genes, which we assume to be involved in their biosynthesis, have not been characterized.

Glucosinolates are secondary metabolites found in the Capparales order, which includes important crops such as rape and Brassica vegetables e.g. broccoli and cabbage. Glucosinolates and their hydrolysis products have a wide range of biological effects e.g. as defence compounds, attractants for herbivorous insects, bioher- 
bicides, and flavour compounds. Glucosinolates are related to cyanogenic glucosides, which are widely spread in the plant kingdom. Both groups of plant metabolites are derived from amino acids and have oxime as intermediates. In the biosynthesis of the tyrosine-derived cyanogenic glucoside dhurrin from Sorghum bicolor, a multifunctional P450, CYP79A1, catalyzes the conversion of tyrosine to the corresponding oxime. CYP79B1 cDNA was also isolated from Sinapis alba. The cDNA shows $54 \%$ sequence identity to CYP79A1 and 95\% identity to the full length cDNA of the Arabidopsis homologue assigned CYP79B2. At present the enzymatic activity of CYP79B1 and CYP79B2 is not known, but the sequence identity and similarity with CYP79A1 strongly indicates that the CYP79B species catalyze the conversion of amino acids to their corresponding oximes in the biosynthesis of glucosinolates.

The cyclic hydroxamic acids DIBOA (2,4-dihydroxy1,4-benzoxazin-3-one) and DIMBOA (2,4-dihydroxy7-methoxy-1,4-benzoxazin-3-one) are secondary metabolites of grasses that function as natural pesticides. Bacteria, fungi and especially the European corn borer, one of the most harmful insects in corn agriculture, are controlled efficiently by high DIMBOA levels. In maize, a series of five genes that are clustered on the short arm of chromosome four, is sufficient to encode the enzymes to synthesize DIBOA. The first gene of the pathway, Bxl, encodes an enzyme resembling $\alpha$ tryptophan synthase subunit and catalyses the formation of free indole. At this point the DI(M)BOA biosynthesis branches off the primary biosynthetic pathway. Four cytochrome P450-dependent monooxygenases, Bx2 through $\mathrm{Bx} 5$, catalyze four consecutive hydroxylations including one ring-expansion to form the defense compound DIBOA out of the source substrate indole. The genes $\mathrm{Bx} 2-\mathrm{Bx} 5$ belong to one cytochrome $\mathrm{P} 450$ subfamily, CYP71C, and have similar gene structures. Their homology and the formation of a gene cluster indicate that $\mathrm{Bx} 2-\mathrm{Bx} 5$ probably evolved by gene duplication events. Heterologous expression in yeast demonstrates that each DIMBOA specific reaction can be performed by only one enzyme of the subfamily.

cDNA clones of P450 species related to metabolism of the herbicide chlortoluron were isolated from cultured tobacco S401 cells, since the cells treated with 2,4-D showed an enhanced metabolism of chlortoluron. Two cDNA clones encoded CYP81B2 and CYP71A11 were cloned and each expressed in the yeast. On coexpression with yeast or tobacco P450 reductase, CYP81B2 showed $m$-methyl hydroxylation, and CYP71A11 exhibited both $N$-demethylation and $m$-methyl hydroxylation of chlortoluron. Therefore, both CYP71A11 and CYP81B2 were found to be involved in the metabolism of chlortoluron in tobacco S401 cells treated with 2,4-D. It was also found that CYP76B1 from Helianthus tuberosus catalyzed oxidation of several phenylurea herbicides. On the other hand, CYP71A11 was highly induced in tobacco S401 cells by treatment with 2,4-D, naphthalic anhydride and others. Also, CYP76B1 was induced by foreign chemicals. Therefore, these $\mathrm{P} 450$ species seem to be the targets for herbicide safeners.

\section{Gene Engineering of P450 Monooxygenases}

\section{Arabidopsis T-DNA mutants}

Feldmann et al., ${ }^{30)}$ described a reverse genetics approach making use of the large collection of T-DNA (the region of the $\mathrm{Ti}$ plasmids responsible for tumour formation) insertion mutants in $A$. thaliana and the vast array of DNA sequences to identify insertion mutants for P450 genes. The isolated mutants are then screened for specific alteration in plant growth and development as related to P450 species. A. thaliana has become the organism of choice for the genetic analysis of plant biology and is ideally suited to laboratory studies. Small enough so that several thousand seeds can be germinated in a petri dish, it is self-fertilizing and can produce over 10,000 seeds per individual. The Arabidopsis life cycle (5-8 weeks in the laboratory) facilitates mutant identification and genetic analysis. Its small genome size (about $120 \mathrm{Mb}$ ) and paucity of repeated sequences are virtually ideal for the reverse genetics strategy. A substantial database of partially sequenced cDNA clones or ESTs (Expressed Sequence Tags) has been growing due to the efforts of a number of laboratories worldwide. Combined with these many attributes is an ever growing population of insertion mutants undoubtedly. Arabidopsis is among only a handful of biological model systems which possess such an assemblage of features and resources. The insertion of a known segment of DNA into a gene of interest has been an extremely valuable research tool for a variety of systems, including bacteria, Drosophila, C. elegans, maize and Antirrhinum majus in addition to Arabidopsis. The unique feature of foreign DNA as a mutagen is that the inserted sequence not only creates a mutation but also "tags" the affected gene, facilitating its molecular isolation. T-DNA integrates randomly and in low copy number in Arabidopsis. After segregation analysis of a large number of transformants, Feldmann et al., concluded that the average number of independent inserts per transformant is 1.5 per diploid genome. Within the context of a target gene, insertion appears random; $\mathrm{T}$ DNAs have been found in exons, introns, and in the $5^{\prime}$ and $3^{\prime}$ flanking regions of the more than 40 genes that have been characterized. To date, more than $70 \mathrm{~T}$ DNAs that have been mapped to specific loci. Since they are largely found in genes previously identified by physical or chemical mutagenesis, it appears that, at the chromosomal level, T-DNA has no significant target-site 
preference; no obvious insertional hot spots have been detected.

Feldmann et al., have identified a null mutation in a CYP90B which resulted in a dwarf phenotype. Cosegregation analysis with the runty phenotype also showed that it was linked to the disrupted CYP83B1. They plan to have them screened for obvious mutations as well as alterations in stress signaling, phenolics, fatty acid metabolism, altered sensitivity to plant pathogens, plant-insect interactions, herbicides, etc. This approach appears to be useful for characterization of physiological function of novel P450 species in plants.

\section{Yeast expression system}

The yeast Saccaromyces cerevisiae contains intracellular organels similar to mammalian cells and can be well used as a simple model of eukaryotic cells. Oeda et $a l .,(1985)^{31)}$ first succeeded in the functional expression of a rat liver microsomal CYP1A1 cDNA in the yeast. Rat CYP1A1 cDNA was placed between alcohol dehydrogenase I $(\mathrm{ADH})$ promoter and terminator regions of the expression vector pAAH5 to construct an expression plasmid, which was introduced into $S$. cerevisiae $\mathrm{AH} 22$ cells by the $\mathrm{LiCl}$ method. The transformed yeast cells produced CYP1A1 holoenzyme at the level of $4 \times 10^{5}$ molecules per cell as determined by the reduced $\mathrm{CO}$ difference spectrum. Although yeast microsomes possess endogenous P450 responsible for sterol biosynthesis and $\mathrm{P} 450$ species inducible under the culture conditions of a high glucose concentration, these contents were extremely low under the aerobic culture conditions used for the experiment. Actually, no P450 peak was detected in the spectrum of the whole yeast cells transformed with the vector plasmid carrying no CYP1A1 cDNA. The produced rat CYP1A1 was mainly located in the yeast microsomal fraction. Both whole cells and microsomal fraction of the transformed yeast cells showed P450-dependent monooxygenase activities toward acetanilide, 7-ethoxycoumarin and benzo( $a)$ pyrene. Therefore, the recombinant CYP1A1 was found to interact with yeast endogenous $\mathrm{P} 450$ reductase in the microsomes to exhibit P450-dependent monooxygenase activities.

The yeast expression system is useful for characterization of enzymatic function of P450 species whose cDNAs were cloned and expressed in the system. In addition, the recombinant yeast cells expressing P450 species have a potential for bioconversion of chemicals to produce valuable compounds as well as bioremediation of environmental chemicals to degrade to harmless chemicals.

\section{Transgenic plants}

P450 cDNA or genes isolated from various sources were each expressed in higher plant for crop improvement (Table 6). ${ }^{32-39)}$ Two sulfonylurea hydroxylase
Table 6 Crop improvement.

\begin{tabular}{ll}
\hline \multicolumn{1}{c}{ P450 species } & \multicolumn{1}{c}{ Crop variety } \\
\hline Flavonoid 3', 5'-hydroxylase & Blue flower varieties \\
Bacterial P450SU1 & Male sterile lines \\
Xenobiotic-metabolizing & Crop varieties resistant to \\
P450 species & herbicides and metabolizing \\
& pesticide residues \\
\hline
\end{tabular}

P450 species have been characterized from the bacterium Streptomyces griseolus. These enzymes P450SU1 (CYP105A1) and P450SU2 (CYP105B1) are substantially different in their primary sequence ( $\sim 44 \%$ identical), and while both are capable of hydroxylating a variety of herbicides. Both enzymes catalyze the $o$-demethylation of chlorimuron ethyl with P450SU2 about 10-fold faster, only P450SU1 is capable of the $N$-dealkylation of the pro-herbicide R7402. P450SU1 cDNA was expressed in tobacco plants, which showed sensitivity to R7402.

Since mammalian CYP1A1 metabolized the herbicides chlortoluron via ring-methyl hydroxylation and $N$ demethylation, and atrazine via $N$-dealkylation at higher rates than tobacco CYP81B2 and CYP71A11, it was attempted to express rat CYP1A1 cDNA under the control of CaMV35S promoter and NOS terminator in potato plants and rat CYP1A1 fused with yeast P450 reductase in tobacco plants. Both transgenic plants expressing the corresponding enzymes which were mainly located on the microsomes, exhibited a higher P450dependent monooxygenase activity towards 7ethoxycoumarin than did the control plants in vitro. The transgenic plants expressing rat CYP1A1 and its fused enzyme showed resistance to chlortoluron. ${ }^{14} \mathrm{C}$ Chlortoluron added to a nutrient solution was taken up by the transgenic and control plants similarly. Analysis of ${ }^{14} \mathrm{C}$-metabolites revealed that the transgenic plant metabolized the herbicide more rapidly than did the control plants via both ring-methyl hydroxylation and $N$-demethylation. Enhanced ring-methyl hydroxylation in the transgenic plants appeared to be responsible for resistance to the herbicide. These transgenic plants also exhibited resistance to the herbicides atrazine and pyriminobac-methyl. Thus, it was found that the expression of single CYP1A1 in plants conferred crossresistance to the herbicides with different structures and modes of herbicide action. This approach appears to be useful for generation of selective herbicide-tolerance crops, since many of herbicide chemicals were found to be metabolized by P450-dependent monooxygenases in mammals. The transgenic plants expressing $\mathrm{P} 450$ species metabolizing herbicides also may be useful for phytoremediation, since mammalian P450 species metabolizing xenobiotics have broad and overlapping substrate specificity each other. 


\section{Concluding Remarks}

P450 genes are members of one of the most structurally diverse and functionally versatile superfamilies of genes. Estimates from current genome projects imply that the number of P450 genes exceeds 50-70 in mammals, 80 in D. melanogaster and C. elegans and 400 in A. thaliana. The yeast genome has yielded three P450 genes.

It is well known that P450 enzymes are involved in both biosynthesis of secondary metabolites and xenobiotic metabolism. Although the general outlines of P450 functions are known, elucidation of specific functions of each P450 species is slow and difficult. Heterologus expression of P450 cDNAs followed by a screen for potential substrates is the current method of choice. P450 enzymes must be reconstituted with P450 reductase, NADPH and phospholipids for enzymatic activity. In the case of higher plants, Feldmann et al., reported a reverse genetics approach making use of the large collection of T-DNA insertion mutants are then screened for specific alteration in plant phenotypes as related to $\mathrm{P} 450$ species.

Isolated P450 cDNAs or genes are often expressed in heterologus cells including yeast. Recombinant cells or P450 enzymes are assayed for P450-dependent monooxygenase activities or screened for agrochemicals which react with the target enzymes or induce the target genes. This approach is reliable for discovery of a novel agrochemical which function on P450 enzymes or P450 genes as found with fungicides, herbicides, plant growth regulators, insecticide synergists and herbicide safeners.

Isolated P450 cDNAs or genes are also expressed in higher plants. For example, mammalian P450 species were screened for metabolism of certain herbicide chemicals. Then selected $\mathrm{P} 450$ species were expressed in transgenic plants, which metabolized the corresponding herbicides and showed resistance to the herbicides. This approach is useful for generation of selective herbicide tolerance plants which reduce not only herbicides but also other pesticide residues. The combined use of a novel herbicide and herbicide tolerance crops specific to the herbicide appears to be important for construction of the system of sustainable agriculture in the future.

\section{REFERENCES}

1) D. R. Nelson: "Cytochrome P450, Structure, Mechanism, and Biochemistry," second edition, ed. by P. R. Ortiz de Montellano, Plenum Pres, New York, pp. 575-606, 1995

2) D. R. Nelson, L. Koymans, T. Kamataki, J. J. Stegeman, R. Feyereisen, D. J. Waxman, M. R. Waterman, O. Gotoh, M. J. Coon, R. W. Estabrook, I. C. Gunsalus \& D. W. Nebert: Pharmacogenetics 6, 1 (1996)

3) P. B. Danielson, J. L. Foster, M. M. McMahill, M. K. Smith \& J. C. Fogleman: Mol. Gen. Genet. 259, 54 (1998)

4) S. Maitra, S. M. Dombrowski, L. C. Waters \& R. Ganguly:
Gene 180, 165 (1996)

5) S. M. Dombrowski, R. Krishnan, M. Witte, S. Maitra, C. Diesing, L. C. Waters \& R. Ganguly: Gene 221, 69 (1998)

6) B. C. Dunkov, V. M. Guzov, G. Mocelin, F. Shotkoski, A. Brun, M. Amichot, R. H. Ffrench-Constant \& R. Feyereisen: DNA Cell Biol. 16, 1345 (1997)

7) A. Brun, A. Cuany, T. Le Mouel, J. Berge \& M. Amichot: Incect Biochem. Mol. Biol. 26, 697 (1996)

8) C. Saner, B. Weibel, F. E. Wurgler \& C. Sengstag: Environ. Mol. Mutagen. 27, 46 (1996)

9) T. Tomita \& J. G. Scott: Insect. Biochem. Mol. Biol. 25, 275 (1995)

10) R. L. Rose, D. Goh, D. M. Thompson, K. D. Verma, D. G. Heckel, L. J. Gahan, R. M. Roe \& E. Hodgson: Insect. Biochem. Mol. Biol. 27, 605 (1997)

11) P. B. Danielson \& J. C. Fogleman: Insect. Biochem. Mol. Biol. 27, 595 (1997)

12) M. H. Bassett, J. L. McCarthy, M. R. Waterman \& T. J. Sliter: Mol. Cell. Endocrinol. 131, 39 (1997)

13) J. G. van Nistelrooy, J. M. van den Brink, J. A. van Kan, R. F. van Gorcom \& M. A. de Waard: Mol. Gen. Genet. 250, 725 (1996)

14) F. Cabello-Hurtado, A. Zimmerlin, A. Rahier, M. Taton, R. DeRose, S. Nedelkina, Y. Batard, F. Durst, K. E. Pallett \& D. Werck-Reichhart: Biochem. Biophys. Res. Commun. 230, 381 (1997)

15) J. A. Maughan, J. H. Nugent \& D. L. Hallahan: Arch. Biochem. Biophys. 341, 104 (1997)

16) M. Mizutani, D. Ohta \& R. Sato: Plant Physiol. 113, 755 (1997)

17) P. Urban, C. Mignotte, M. Kazmaier, F. Delorme \& D. Pompon: J. Biol. Chem. 272, 19176 (1997)

18) Y. Batard, M. LeRet, M. Schalk, T. Robineau, F. Durst \& D. Werck-Reichharrt: Plant J. 14, 11 (1998)

19) S. Bak, H. L. Nielson \& B. A. Halkier: Plant Mol. Biol. 38, 725 (1998)

20) H. H. Pauli \& T. M. Kutchan: Plant J. 13, 793 (1998)

21) K. Meyer, J. C. Cusumano, C. Somerville \& C. C. Chapple: Proc. Natl. Acad. Sci. USA 93, 6869 (1996)

22) I. Benveniste, N. Tijet, F. Adas, G. Philipps, J. P. Salaun \& F. Durst: Biochem. Biophys. Res. Commun. 243, 688 (1998)

23) K. Salchert, R. Bhalerao, Z. Koncz-Kalman \& C. Koncz: Philos. Trans. R. Soc. Lond. B. Biol. Sci. 353, 1517 (1998)

24) M. Szekeres, K. Nemeth, Z. Koncz-Kalman, J. Mathur, A. Kauschmann, T. Altmann, G. P. Redei, F. Nagy, J. Schell \& C. Koncz: Cell 85, 171 (1996)

25) J. Mathur, G. Molnar, A. Fujioka, S. Takatsuto, A. Sakurai, T. Yokota, G. Adam, B. Voigt, F. Nagy, C. Maas, J. Schell, C. Koncz \& M. Szekeres: Plant J. 14, 593 (1998)

26) G. T. Kim, H. Tsukaya \& H. Uchimiya: Genes Dev. 12, 2381 (1998)

27) C. R. Schopfer, G. Kochs, F. Lottspeich \& J. Ebel: FEBS Lett. 432, 182 (1998)

28) N. Tijet, C. Helvig, F. Pinot, R. Le Bouquin, A. Lesot \& F. Durst, J. P. Salaun, I. Benveniste: Biochem. J. 332, 583 (1998)

29) M. Frey, P. Chomet, E. Glawischinig, C. Stettner S. Grun, A. Winklmair, W. Eisenreich, A. Bacher, R. B. Meeley, S. P. Briggs, K. Simcox, \& A. Gierl: Science 227, 696 (1997)

30) R. G. Winkler, M. R. Frank, D. W. Galbraith, R. Feyereisen \& K. A. Feldmann: Plant Physiol. 118, 743 (1998)

31) K. Oeda, T. Sakaki \& H. Ohkawa: DNA 4, 203 (1985) 
32) N. Shiota, A. Nagasawa, T. Sakaki, Y. Yabusaki \& H. Ohkawa: Plant Physiol. 106, 17 (1994)

33) H. Inui, N. Shiota, T. Ishige, Y. Ohkawa \& H. Ohkawa: Breed. Sci. 48, 135 (1998)

34) Y. Yabusaki \& H. Ohkawa: "Microbial and Plant Cytochromes P450: Biochemical Characteristics, Genetic Engineering and Practical Implications," ed. by K. Ruckpaul and H. Rein, Akademic Verlag, Berlin, pp. 169-190, 1991

35) H. Ohkawa, H. Imaishi, N. Shiota, H. Inui \& Y. Ohkawa: Rev. Toxicol. 2, 245 (1998)

36) H. Ohkawa, N. Shiota, H. Inui, M. Sugiura, Y. Yabusaki, Y. Ohkawa \& T. Ishige: "Regulation of Enzymatic Systems Detoxifying Xenobiotics in Plants," ed. by K. K. Hatzios, Kluwer Academic Publishers, Netherlands, pp. 307-312, 1997

37) H. Ohkawa, H. Imaishi, N. Shiota, T. Yamada, H. Inui \& Y. Ohkawa: Plant Biotechnol. 15, 173 (1998)

38) D. P. O'Keefe, J. M. Tepperman, C. Dean, K. J. Leto, D. L. Erbes \& J. T. Odell: Plant Physiol. 105, 473 (1994)

39) Y. Tanaka, S. Tsuda \& T. Kusumi: Plant Cell Physiol. 39, 1119 (1998)

要 約

\section{チトクロームP450のバイオダイバシティと植物 保護}

大川秀郎, 辻井久恵, 下地みゆき, 今宿芳郎, 今石浩正

チトクロームP450モノオキシゲナーゼは農薬などの外 来性化合物の解毒または活性化に, 並びに, 殺菌剤, 植物 成長調節剤, 殺虫共力剂, 除草剂セイフナーなどの作用点 として重要である。

最近のゲノムプロジェクトの成果により, P450 遺伝子は 生物界のバクテリア，プロトゾア，植物，動物，糸状菌の すべてに分布しており，動物や植物の種には多くの遺伝子 が存在することが明らかになった．特に，モデル植物であ るシロイヌナズナには約 400 の遺伝子が存在すると推定さ れている.

これら P450酵素の生化学的性質を明らかにすること が，生理学的な役割の解明に重要である，高等植物では， シロイヌナズナ T-DNA 変異株を用いた研究が生理学的な 役割の解明に有効であり，また，酵母を用いた遺伝子発現 系は実際に酵素機能の解明に広く用いられている.さらに， 薬物代謝に係わるP450 分子種を発現したトランスジェニ ク植物の作出は, 除草剤選択性植物やファイトレメディ エーション用植物の育成に重要である. 